\title{
Pesan Dakwah Nahi Mungkar di Media Sosial Instagram
}

\author{
Arman Muharam*, Siti Sumijaty, \& Uwes Fatoni \\ Jurusan Komunikasi dan Penyiaran Islam, Fakultas Dakwah dan Komunikasi, \\ UIN Sunan Gunung Djati, Bandung \\ *Email : armanmubaram96@gmail.com
}

\begin{abstract}
This research is to explain the message of preaching mungkar mungkear in social media Instagram which is formulated in three discussions related to the message of preaching nabi mungkar in the form of explanation, form of advice, and prevention in the Instagram account (a) indonesiatanpapacaran. The method used in this study is a qualitative content analysis method, namely by analyzing using coding sheets and making descriptive qualitative as a form of data preparation which is then explained, analyzed, which is carried out simultaneously with data collection. The results found that on the Instagram account@Indonesiatanpaparan during February 2019 there were 135 messages about nabi, including 110 uploads in the form of images or captions and 25 uploads in the form of videos. The message of preaching nabi mungkar forms of explanation is divided into the message of faith, sharia, and morals. Message preaching nahi mungkear form of advice in the form of wisdom messages, advice in the form of hasanah mavidzah, and advice in the form of mujadalah. The message of preaching mungkar mungkar form of prevention found to be preventive, repressive, and curative.
\end{abstract}

Keywords: massage of da'wah; nabi mungkar; social media

\begin{abstract}
ABSTRAK
Penelitian ini untuk menjelaskan pesan dakwah nahi mungkar dalam media sosial instagram yang terumuskan pada tiga pembahasan terkait pesan dakwah nahi mungkar bentuk penjelasan, bentuk nasihat, dan pencegahan dalam akun instagram@indonesiatanpapacaran. Adapun metode yang digunakan dalam penelitian ini yaitu metode analisis isi kualitatif yakni dengan melakukan analisis mengggunakan coding sheet dan membuat deskriptif kualitatif sebagai bentuk penyusunan data yang kemudian dijelaskan, dianalisis, yang dilakukan bersamaan dengan pengumpulan data. Hasil penelitian menemukan bahwa pada akun instagram@Indonesiatanpapacaran selama bulan Februari 2019 terdapat 135 pesan tentang nahi, diantaranya 110 unggahan berupa gambar atau caption dan 25 unggahan berupa video. Pesan dakwah nahi mungkar bentuk penjelasan terbagi pada pesan akidah, syariah, dan akhlak. Pesan dakwah nahi mungkar bentuk nasihat berupa pesan hikmah, nasihat berupa mauidæah basanah, dan nasihat berupa
\end{abstract}


A. Muharam, S. Sumijaty, \& U. Fatoni

mujadalah. Pesan dakwah nahi mungkar bentuk pencegahan ditemukan bersifat preventif, represif, dan kuratif.

Kata Kunci : pesan dakwah; nahi mungkar; media sosial

\section{PENDAHULUAN}

Kemajuan teknologi, telah membuat banyak perubahan diberbagai bidang kehidupan. Salah satu bentuk kemajuan ini, bisa dilihat pada bidang teknologi informasi dan komunikasi yang saat ini semakin maju guna mempermudah manusia berinteraksi. Berbagai macam infromasi bisa diakses dengan mudah dan cepat, sehingga orang dapat mengetahui berbagai informasi maupun peristiwa yang sedang terjadi pada waktu yang bersamaan hanya dengan mengakses ragam media yang sesuai dengan kebutuhannya.

Salah bentuk kemajuan perkembangan teknologi informasi ini yaitu dengan munculnya berbagai media berbasis internet atau yang saat ini disebut sebagai media baru (new media). Karena karakteristiknya yang bersifat network (jejaring), dimana network ini merupakan jembatan yang menghubungkan satu pengguna dengan pengguna yang lainnya, serta dengan perangkat eksternal lain, memungkinkan pengguna untuk dapat berkomunikasi dan bertukar informasi secara luas. Media baru menjadi salah satu media yang kini sering digunakan untuk menyampaikan suatu pesan kepada khalayak luas dengan menggunakan jaringan teknologi informasi dan komunikasi, yang termasuk kedalam kategori media baru adalah internet, website, serta komputer multimedia. Banyak hal yang dapat diakses dan dicari melalui media baru. Baik yang sifatnya hiburan maupun edukasi. Salah satu media baru yang memberikan keluasan informasi dalam kehidupan saat ini yaitu melalui media sosial.

Media sosial dapat diartikan sebagai alat yang digunakan oleh orang-orang untuk berinteraksi maupun bertukar informasi dengan pengguna lain yang terkoneksi dengan jaringan internet dalam bentuk komunikasi virtual. Media sosial adalah sebuah medium yang terkoneksi dengan jaringan internet dimana setiap penggunannya bisa secara mudah berbagi serta berpartisipasi (Kusnawan, 2016: 207). Melalui media sosial pengguna bisa langsung berbagi maupun bertukar informasi dalam waktu yang terbilang cepat. Dikarenakan sifatnya yang menggambarkan kemudahan, membuat pengguna mudah untuk mengakses media sosial. Berdasarkan data yang diperoleh dari wearesocial.com di tahun 2018, tercatat sebanyak 130 juta orang di Indonesia merupakan pengguna aktif di sosial media dengan penetrasi 49\%. Hal ini menjelaskan bahwa Indonesia termasuk dalam salah satu negara dengan pengguna aktif terbanyak di media sosial (Hartono: 2018).

Melihat banyaknya pengguna media sosial di Indonesia, dapat diartikan bahwa penerapan media sosial dalam kehidupan saat ini juga mampu mengubah ragam interaksi manusia secara signifikan. Seiring pesatnya teknologi informasi, saat ini juga membuat pengguna dapat menyerap berbagai informasi dari berbagai 
platform media. Tidak dipungkiri bahwa pertukaran informasi ini juga membawa budaya lain masuk ke dalam kehidupan, baik yang berdampak positif maupun negatif. Salah satu bentuk masuknya budaya luar ke dalam kehidupan adalah budaya pacaran atau menjalin hubungan dengan lawan jenis tanpa adanya ikatan yang sah. Pacaran yang identik dengan aktivitas saling berpandangan, saling berdekatan, berpegangan tangan, dll sangatlah tidak sesuai dengan ajaran Islam.

Di Indonesia, tidak sedikit remaja muslim yang melakukan hubungan pacaran dan tidak sedikit pula bahwa pertemuan mereka berawal melalui media sosial. Bahkan media sosial juga membawa pengaruh yang signifikan pada gaya pacaran mereka. Dari sekadar hanya mengunggah poto mesra berdua, hingga melakukan tindakan-tindakan yang tidak semestinya dilakukan sebelum adanya ikatan pernikahan. Hal ini tentu membuat kejahatan asusila semakin marak terjadi. Seperti tindakan pelecehan seksual, pemerkosaan, hamil diluar nikah, hingga pembunuhan. Menurut Badan Kependudukan dan Keluarga Berencana Nasional (BKKBN) menyebutkan bahwa angka kehamilan di luar nikah secara nasional di tahun 2017 mencapai 10,2\% (Metropolis: 2017). Hal ini terjadi disebabkan oleh faktor ekonomi dan faktor pergaulan bebas (khususnya di media sosial).

Selain itu bahaya media sosial juga berbentuk penyebaran informasi hoax yang informasinya tidak benar yang seringkali diterima oleh masyarakat tanpa melakukan filter. Ketergantungan pada gadget dan mudahnya menshare berita menjadi penyebab setiap orang menjadi agen penyebar hoax di media sosial (Tohari, Muhlis \& Fatoni, 2019: 74).

Hal ini membuat dakwah di media sosial dirasa perlu dilakukan. Sebagai upaya menghalau masuknya budaya maupun pengaruh luar yang negatif dan tidak sesuai dengan ajaran Islam salah satunya yaitu berpacaran. Berpacaran merupakan salah satu bentuk kemungkaran yang harus dijauhi bagi setiap umat Islam, karena berpacaran termasuk ke dalam salah satu perbuatan yang dapat mendekatkan pelakunya pada kemaksiatan dan perzinahan.

Pada hakikatnya, dakwah Islam adalah sebuah upaya untuk menyampaikan ajaran Islam kepada seluruh umat manusia. Sebagai sebuah proses, dakwah tidak hanya diartikan sebagai usaha menyampaikan, namun dakwah dapat diartikan sebagai kegiatan untuk merubah pola pikir, merasakan, serta cara hidup manusia sebagai target dakwah guna meraih hidup yang lebih baik. Dakwah melalui internet adalah salah satu inovasi baru di dalam proses mensyiarkan ajaran Islam. Dengan memanfaatkan internet sebagai sebagai sarana berdakwah membuat proses penyebaran dakwah mudah dilakukan. Kehadiran internet sebagai ruang sosial baru merupakan suatu peluang baru dalam aktivitas dakwah.

Media sosial merupakan salah satu media yang memliki peluang besar dalam menyebarkan pesan dakwah Islam. Sebagaimana diketahui bahwa media sosial menjadi media penyebar informasi yang mudah dan cepat. Adapun Bentuk media sosial yang saat ini banyak digunakan yaitu media sosial Instagram. Instagram adalah sebuah media untuk mengunggah foto yang kemudian mengirimkannya ke dalam akun pengguna Instagram tersebut. Dewasa ini, media sosial instagram tidak hanya berfungsi untuk mengunggah foto, bahkan video pun sudah bisa 
dilakukan, dan tak jarang pengguna menambahkan kata-kata maupun keterangan pada setiap unggahannya. Memanfaatkannya sebagai media untuk berdakwah dinilai sangat efektif dan efisien untuk dilakukan. Hal ini terbukti dengan banyaknya akun-akun instagram yang memfungsikannya sebagai sarana untuk berdakwah.

Salah satu akun instagram yang bertemakan dakwah dengan jumlah pengikut sebanyak 910 ribu adalah akun instagram@Indonesiatanpapacaran, akun ini mengangkat tema tentang larangan berpacaran dalam Islam pada setiap unggahannya. Akun@indonesiatanpapacaran ini memliki tujuan untuk mengajak remaja muslim untuk tidak melakukan hubungan berpacaran. Maka dari itu peneliti merasa tertarik untuk menjadikan akun instagram @indonesiatanpapacran sebagai objek penelitian peneliti.

Terdapat penelitian-penelian sejenis yang relevan dengan penelitian ini diantaranya: (1) Ahmad Pakhri M, tahun 2017 meneliti tentang penggunaan fitur vidgram sebagai tren media dakwah, dtemukan bahwa pada akun @yuvid.tv di instagram mencakup pokok-pokok materi dakwah yaitu akidah, syariat, muamalah, dan akhlak. (2) Rusti Yanti, tahun 2009 meneliti tentang analisis isi pesan dakwah dalam sinopsis film mengaku rasul, ditemukan bahwa pada sinopsis film tersebut terdapat pesan-pesan berupa akidah, akhlak, dan muamalah. Perbedaan penelitian ini dengan penelitian sebelumnya yaitu pada objek pembahasan dimana dalam penelitian ini membahas pesan dakwah nahi mungkar pada akun instagram @Indonesiatanpapacaran yang belum dibahas pada penelitian sebelumnya.

Dakwah dapat diartikan sebagai seruan atau ajakan kepada jalan kebaikan. Secara istilah dakwah merupakan proses islamisasi, yakni suatu usaha untuk mempertahankan keislaman setiap manusia yang beragama Islam serta suatu proses pengupayaan seseorang yang ingkar agar kembali meyakini dan mengamalkan ajaran Islam (Sukayat, 2009: 2). Proses dakwah dapat berupa mengajak, memanggil, menyeru seseorang baik dalam bentuk lisan, tulisan serta tindakan-tindakan yang dilakukan secara nyata dan terencana dalam upaya mempengaruhi objek dakwah kepada jalan kebaikan. Melakukan proses dakwah bukan hanya semata-mata sebuah kewajiban melainkan juga menjadi sebuah kebutuhan untuk saling memberi motivasi serta saling mengingatkan satu sama lain agar selalu berada di jalan Allah Swt. Muhaemin (2017: 341) mengatakan bahwa dakwah menjadi langkah strategis dalam mengubah keadaan suatu masyarakat ke arah yang lebih baik. Dalam konsepsi Islam, kendati zaman dan perkembangan teknologi berkembang dengan sangat cepat, dakwah adalah sesuatu yang mutlak adanya dan tidak bisa diabaikan.

Tujuan dakwah Islam yakni untuk merubah sikap buruk seseorang menjadi lebih baik, serta memberikan pemahaman agar senantiasa ingat dan patuh pada perintah Allah. Hal ini selaras dengan tujuan Islam sendiri yaitu adanya perubahan (transformasi) sikap kemanusiaan dari objek dakwah (Ismail, 2011: 58). Dakwah merupakan suatu rangkaian kegiatan yang di dalamnya melibatkan unsur-unsur 
tertentu agar tercapainya suatu tujuan dakwah. Adapun unsur-unsur dakwah yang dimaksud diantaranya: da'i, mad'u, materi atau pesan, media, efek, dan metode dakwah.

Salah satu unsur terpenting agar terciptanya suatu kegiatan dakwah yaitu adanya materi atau pesan dakwah (maddab). Pesan dapat diartikan sebagai sebuah nasihat, amanat, permintaan, atau perintah yang harus disampaikan kepada penerima pesan. Pesan dakwah merupakan bahan atau isi ceramah yang akan disampaikan oleh da'i kepada mad'u baik berupa nasihat, peringatan, maupun perintah agar selalu taat kepada Allah Swt guna tercapainya suatu proses dakwah. Pesan dakwah melingkupi segala aspek kehidupan manusia. Jenis pesan apapun dapat dijadikan sebagai pesan dakwah selama pesan tersebut mengandung nilai kebaikan serta tidak bertentangan dengan sumber utamanya. Bahan dasar atau materi utama dakwah adalah Alquran dan Hadis, ditambah dengan pendapat para sahabat, pendapat ulama, kisah-kisah teladan, serta berita dan peristiwa (Kamaluddin, 2016: 40).

Dalam proses pembuatan pesan atau materi dakwah terdapat beberapa hal atau ciri yang perlu diperhatikan agar pesan yang disampaikan sesuai dan tidak bertentangan dengan ajaran maupun sumber Islam. Moh. Ali Aziz (2009: 342) mengatakan bahwa diantara ciri atau karakteristik pesan dakwah tersebut yaitu: orisinalitas (pesan yang dsampaikan bersumber dari Allah Swt), universal (pesan dakwah mencakup segala aspek kehidupan manusia), mudah, lengkap, seimbang, rasional, dan membawa kebaikan. Namun, berbeda halnya jika kita akan menyampaikan pesan dakwah pada platform media sosial, selain memperhatikan karakteristik pesan dakwah yang disampaikan, da'i juga harus dapat mengemas pesan dakwah tersebut agar terlihat menarik, lugas, dan tidak bertele-tele. Musthafa (2016: 53) mengemukakan terdapat dua hal yang harus diperhatikan dalam membuat pesan dakwah di media sosial. Pertama, materi yang disampaikan harus merujuk pada sumber nash asli (Alquran dan Hadis). Kedua, pesan dakwah yang disampaikan bersifat memotivasi atau mendorong sasaran dakwah untuk bergerak atau berbuat artinya memberi dorongan untuk berubah pada mad'u.

Dalam proses penyampaian pesan dakwah saat ini, para da'i banyak membahas terkait pesan-pesan dakwah terkait amar makruf sedangkan pesanpesan dakwah terkait kemugkaran terbilang masih sedikit dibahas oleh para da'i. Padahal dalam proses penyampaiannya pesan dakwah harus berimbang dengan maksud ketika para da'i menyampaikan pesan dakwah terkait amar makruf maka para da'i juga harus menyentuh pesan dakwah terkait nahi mungkar.

Dakwah nahi mungkar dapat dipahami sebagai suatu usaha untuk melenyapkan dan menghapus kemungkaran pada diri seseorang maupun kelompok agar mereka bisa berhenti serta tidak mengulangi perbuatan mungkar dan menggantinya dengan melakukan perbuatan-perbuatan makruf. Eko dan Wahid (2015: 3) menjelaskan nahi mungkar terbagi pada dua rangkaian kata bahasa Arab, yaitu al-nabyi dan al-munkar. Al-nabyi berarti mencegah melakukan sesuatu dengan perkataan dan perbuatan, sedangkan al-munkar yakni segala perbuatan atau perkataan yang dibenci dan dilarang oleh Allah Swt. 
Islam mempunyai cara-cara atau metode yang tepat dalam menyampaikan kebenaran dan demikian juga dalam merubah kemungkaran, agar pesan yang disampaikan dapat diterima oleh sasaran dakwah. Proses itu harus dilakukan dengan menggunakan langkah-langkah yang baik sehingga orang yang dicegah tersentuh hatinya untuk meninggalkan perbuatan mungkar dan bersedia untuk kembali ke jalan yang benar. Dalam proses melakukan dakwah nahi mungkar seorang da'i harus memperhatikan beberapa hal dalam menyampaikan pesanpesan dakwah terkait kemungkarana. Ikhwani dan Muhammad Iqbal (2016: 56) menuturkan bahwa terdapat tiga fase atau cara yang dapat dilakukan dalam melakukan dakwah nahi mungkar yaitu: dengan memberikan penjelasan, memberi nasihat, serta melakukan pencegahan dengan perkataan.

Untuk mencegah seseorang agar tidak melakukan nahi mungkar yaitu dengan memberikan penjelasan. Memberikan sebuah penjelasan kepada orang yang melakukan perbuatan nahi mungkar bahwa perbuatan tersebut dilarang dan bertentangan dengan Islam. Adapun hal pokok dalam memberikan penjelasan dapat terkait tentang nilai-nilai keislaman yang terbagi pada aspek akidah (keimanan), syariah (hukum), akhlak (budi pekerti), serta aspek muamalah (mencakup segala bentuk komunikasi dan interiaksi diantara manusia).

Langkah kedua dalam mencegah perbuatan kemungkaran yaitu dengan memberikan nasihat. Secara terminologi nasihat adalah memerintah, melarang, atau menganjurkan yang disertai dengan movitasi dan ancaman (Suparta, 2015: 243). Banyak diantara kita yang ketika melihat perbuatan nahi mungkar, langsung bertindak keras dan arogan. Hal ini jelas merupakan tindakan yang tidak dianjurkan. Allah pun menjelaskan perintah nasihat tersebut dalam Qs. An-Nahl ayat 125 yang memerintahkan manusia untuk menyeru dengan hikmah, pelajaran yang baik, dan membantah dengan cara yang baik.

Adapun langkah terakhir dalam mencegah perbuatan nahi mungkar yaitu dengan mencegah dengan perkataan. Memberikan pencegahan dengan perkataanperkataan yang membuat orang tersebut takut untuk melakukan perbuatan nahi mungkar kembali dan kemudian menjauhinya. Syarbaini (2016: 138) mengatakan bahwa di dalam melakukan proses pencegahan atau pengendalian sosial dapat dilakukan dengan tindakan preventif, represif, dan kuratif.

Salah satu bentuk atau media dakwah yang dapat digunakan dalam proses penyampaian pesan dakwah saat ini yaitu melalui media sosial. Medsos atau media sosial adalah sebuah media yang bersifat online atau daring, dimana penggunanya dapat ikut berperan aktif, membagikan hingga menciptakan isi dalam media sosial tersebut (Herman, 2017: 177). Sebagaimana teori media sosial menurut Rulli Nasrullah (2017: 11), meengatakan bahwa media sosial merupakan medium internet yang memungkinkan pengguna mempresentasikan dirinya maupun berinteraksi, bekerja sama, berbagi, berkomunikasi dengan pengguna lain dan membentuk ikatan sosial secara virtual. Media sosial menjadi media yang efektif dalam penyampaikan pesan dakwah dimana penggunanya dapat melakukan 
komunikasi, berinteraksi, serta berkirim pesan antar sesama pengguna media sosial. Bentuk media sosial yang saat banyak digunakan yaitu instagram.

Instagram merupakan produk aplikasi media sosial yang memfasilitasi para pengguna dalam mengambil foto, mengedit, kemudian membagikannya. Selain foto, instagram juga membagikan video yang ingin dibagikan penggunanya. Instagram seperti sebuah galeri raksasa dimana setiap pengguna dapat melihat hasil karya pengguna instagram lainnya serta dapat menciptakan sebuah jaringan pertemanan (Enterprise, 2012: 2). Memanfaatkan Instagram sebagai media dakwah memudahkan para da'i dan mad'u untuk saling berkomunikasi tanpa ada batasan waktu.

Adapun fokus penelitian ini membahas pesan-pesan dakwah nahi munkar yang disampaikan oleh akun@indonesiatanpapacaran baik berupa gambar atau caption maupun video yang diunggah di akun tersebut. yang terumuskan pada tiga pembahasan, diantaranya: (1) pesan dakwah nahi munkar bentuk penjelasan, (2) pesan dakwah nahi munkar bentuk nasihat, dan (3) pesan dakwah nahi munkar bentuk pencegahan.

Sedangkan metode penelitiannya menggunakan metode analisis isi kualitatif. Proses pengumpulan datanya menggunakan coding sheet untuk mencari persamaan dan kesesuaian data antara koder satu dengan koder dua terkait objek penelitian yang sesuai. Kemudian data dikumpulkan, dianalisis, dijelaskan, lalu disimpulkan sebagai hasil penelitian.

\section{HASIL DAN PEMBAHASAN}

Akun@Indonesiatanpapacaran merupakan akun media sosial yang saat ini banyak diikuti oleh para pengguna media sosial instagram khususnya kalangan muda. Akun instagram ini mengambil tema pokok tentang dakwah Islam nahi mungkar, khususnya tentang larangan berpacaran. Hal ini sejalan dengan visi dan tema komunitas ini yaitu sebagai "Gerakan Perjuangan Menghapus Pacaran dari Indonesia”. Gerakan atau komunitas ini dicetuskan oleh Ustadz La Ode Munafar. Sebagaimana dengan visi komunitasnya, akun instagram ini banyak memuat konten-konten dakwah perihal larangan atau bahaya pacaran.

Pada halaman awal akun instagram@Indonesiatanpapaaran ini admin menberikan informasi terkait profil dari akun instagram@Indonesiatanpapacaran yang berisi tentang profil, tagline, kontak, alamat, website resmi, jumlah akun pengikut dan akun yang diikuti, dan konten-konten unggahan akun @Indonesiatanpapacaran. Akun instagram ini beralamatkan di Bantul, Yogyakarta. Akun yang sudak aktif sejak tanggal 10 September tahun 2015 ini kini memiliki jumlah pengikut sebanyak 910 ribu, dengan jumlah konten unggahan sebanyak 31 ribu lebih. Adapun jumlah unggahan akun@Indonesiatanpapacaran ini dalam satu harinya menggunggah sebanyak 32 konten di media sosial instagram (Khalika, 2018).

Konten-konten yang dibuat di dalamnya berupa gambar maupun video yang berisi quotes atau pesan dakwah yang diambil dari Alquran dan hadis maupun 
penggalan isi ceramah dari para ustadz terkait tentang larangan berpacaran. Dalam akun instagram@Indonesiatanpapacaran tersebut terdapat 134 pesan dakwah berupa gambar atau caption dan 28 video bertemakan dakwah pada bulan Februari 2019. Setelah peneliti kumpulkan pada tanggal 1-7 Februari terdapat 28 pesan dakwah berupa gambar atau caption dan 7 pesan dakwah berupa video, pada tanggal 8-15 Februari terdapat 30 pesan dakwah berupa gambar atau caption dan 7 pesan dakwah berupa video, pada tanggal 16-22 Februari terdapat 46 pesan dakwah berupa gambar atau caption dan 7 pesan dakwah berupa video, pada tanggal 23-28 Februari terdapat 29 pesan dakwah berupa gambar atau caption dan 7 pesan dakwah berupa video. Kemudian peneliti kembali mengelompokkannya ke dalam rumusan masalah penelitian yaitu terkait pesan dakwah nahi mungkar bentuk penjelasan, pesan dakwah nahi mungkar bentuk nasihat, dan pesan dakwah nahi mungkar bentuk pencegahan.

\section{Pesan Dakwah Nahi Mungkar Bentuk Penjelasan}

Dalam penyampaian pesan dakwah terdapat berbagai cara atau langkah yang dapat dilakukan untuk membuat mad'u paham termasuk pesan dakwah nahi mungkar. Salah satu bentuk atau langkah yang dapat dilakukan yaitu dengan memberikan penjelasan. Penjelasan adalah sesuatu yang dianggap benar karena suatu alasan atau dengan melakukan pengutaraan pendapat tertentu agar objek yang didakwahi paham. Penjelasan dapat diartikan sebagai suatu proses, cara, dan perbuatan menjelaskan (Dep.Diknas, 2008: 574). Ketika seseorang akan melakukan perbuatan mungkar, maka alangkah baiknya orang tersebut diberikan penjelasan bahwa perbuatan tersebut bertentangan dan dilarang oleh Allah SWT (Ikhwani dan Muhammad Iqbal, 2016: 56). Bentuk penjelasan dalam gambar atau caption pada unggahan akun instagram@Indonesiatanpapacaran ini setelah peneliti dalami, bentuk penjelasan dari unggahan tersebut membahas tentang pesan dakwah nahi mungkar pada aspek akidah, syariah, dan akhlak.

Pertama, pesan dakwah nahi mungkar bentuk penjelasan pada aspek akidah terdapat sebanyak 10 pesan dakwah dalam akun instagram @indonesiatanpapacaran. Adapun contoh temuan aspek akidah tersebut yaitu:

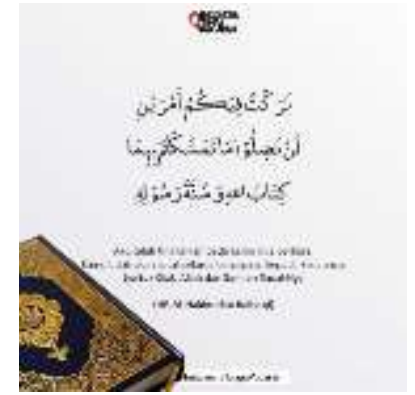

Sumber: akun instagram @Indonesiatanpapacaran

Gambar 1. Iman kepada kitab Allah

Pada gambar 1 kandungan pesan yang terdapat dalam unggahan tersebut 
yaitu mengajak para pembacanya untuk beriman kepada kitab Allah. Bentuk aktualisasi iman kepada kitab Allah yaitu dengan senantiasa selalu membaca, mempelajari, serta memahami isi kandungannya. Dalam isi pesan dakwah pada konten unggahan tersebut menjelaskan bahwa kitab Allah hendaknya dijadikan sebagai pedoman hidup agar kita tidak tersesat. Dengan berpegang teguh kepada kitab Allah yaitu Alquran dan sunnab (hadis) Rasul Saw.

Berkaitan dengan unggahan tersebut, sebagaimana salah satu rukun iman yaitu iman kepada kitab Allah, akun@Indonesiatanpapacaran mengajak para pengikutnya untuk iman kepada kitab Allah terkait akidah. Isi pesan dalam konten unggahan ini digunakan sebagai cara untuk mengukuhkan sikap para pengguna media sosial agar senantiasa berpegang teguh kepada kitab Allah yaitu Alquran. Media sosial merupakan sarana untuk meyakinkan serta menggiring dan menjadikan kepercayaan, sikap, nilai, dan opini seseorang semakin kuat (Vera, 2016: 19).

Kedua, pada aspek syariah pesan dakwah nahi mungkar yang terdapat dalam akun instagram@Indonesiatanpapacaran sebanyak 26 pesan dakwah. Temuan pada unggahan terkait aspek syariah yaitu:

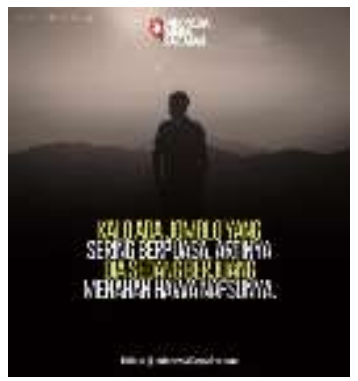

Sumber: akun instagram @indonesiatanpapacaran

Gambar 2. Anjuran menjaga diri

Dalam isi pesan pada gambar 2 tersebut menjelaskan tentang cara bagaimana untuk menjaga atau menahan hawa nafsu yaitu dengan melakukan puasa. Hawa nafsu cenderung membawa manusia kepada perilaku-perilaku yang dilarang oleh Allah Swt. Media sosial cenderung menjadi pelarian sebagai sarana pelampiasan hawa nafsu ketika seseorang sudah tidak bisa mengendalikan hawa nafsunya. Baik atau buruknya pengaruh media sosial, tergantung pada isi konten seseorang yang diunggah pada akunnya. Hal itu dikarenakan konten pada media sosial sepenuhnya milik dan berdasarkan pada kontribusi pengguna atau pemilik akun (Kusnawan, 2016: 210).

Sebagaimana terdapat dalam pesan unggahan tersebut, akun @Indonesiatanpapacaran mengajak para pengikutnya untuk senantiasa menjaga diri dari segala perbuatan yang dapat mendekatkannya pada kemaksiatan dan perzinahan. Salah satu cara yang tepat dalam menjaga diri dari hawa nafsu yaitu dengan melakukan puasa.

Ketiga, pesan dakwah nahi mungkar bentuk penjelasan pada aspek akhlak dalam konten yang diunggah oleh akun instagram@Indonesiatanpapacaran 
pesan dakwah yang pada aspek akhlak terdapat 28 pesan dakwah. Adapun contoh temuan yang membahas terkait aspek akhlak yaitu:

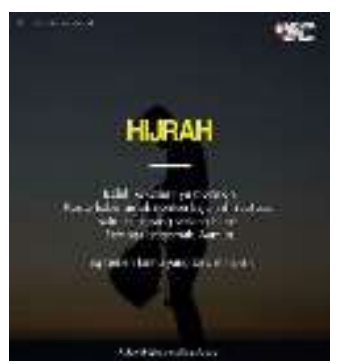

Sumber: akun instagram @Indonesiatanpapacaran

Gambar 3. Hijrah

Konten unggahan gambar 3 berisi tentang suatu perbuatan baik mengenai perubahan diri seseorang ke arah yang lebih baik dengan tujuan agar dapat mendekatkan diri kepada Allah Swt. yaitu dengan melakukan hijrah. Hijrah diartikan sebagai perpindahan seseorang dari suatu tempat atau keadaan ke tempat atau keadaan yang lain (Ismail, 2017: 55). Proses berhijrah berarti meninggalkan segala perbuatan buruk yang dilakukan dimasa lalu dan merubahnya menjadi perbuatan yang baik.

Dalam unggahan akun instagram @Indonesiatanpapacaran tersebut mengajak para pengikutnya untuk senantiasa menjaga akhlak. Hal itu dikarenakan banyaknya pengaruh-pengaruh dari budaya luar yang mudah masuk dan diterima oleh generasi muda salah satunya melalui media sosial. Ini jelas membuat para generasi muda semakin jauh kepada Tuhannya. Media sosial menjadi salah satu media yang memiliki pengaruh cukup besar dalam mempengaruhi pergaulan generasi muda saat ini. Media tersebut dianggap sebagai satu-satunya untuk memenuhi kebutuhan. Seolah-olah manusia tidak bisa lepas dari media (Soliha, 2015: 2).

Untuk itu, isi pesan dakwah dalam konten unggahan tersebut dijadikan sebagai cara untuk menangkal pengaruh-pengaruh buruk media sosial lain. Dengan cara mengajak para pengguna media sosial untuk berhijrah, mendekatkan diri kepada Allah Swt. Ketika media sosial itu digunakan untuk pesan dakwah, maka akan memberikan dampak yang besar, karena karakter dari media sosial sendiri merupakan media penyebaran. Media sosial tidak hanya menghasilkan konten yang dibangun dan dikonsumsi oleh penggunanya, tetapi juga disebarkan dan dikembangkan oleh pengguna lain (Kusnawan, 2016: 211).

\section{Pesan Dakwah Nahi Mungkar Bentuk Nasihat}

Nasihat merupakan suatu ajaran yang baik yang ditujukan kepada seseorang. Menurut kamus besar bahasa Indonesia (2008: 953) nasihat didefinisikan sebagai memberikan petunjuk kepada jalan yang benar, nasihat dapat berupa petunjuk, peringatan, dan teguran. Nasihat juga berarti mengatakan sesuatu yang benar dengan cara melunakkan hati, serta harus berkesan dalam jiwa atau mengikat jiwa 
dengan keimanan dan petunjuk (Suparta, 2015: 243). Dalam pesan dakwah nahi mungkar, nasihat menjadi salah satu fase dalam mencegah kemungkaran. Sebagaimana dijelasakan oleh Ikhwani dan Muhammad Iqbal (2016: 56) bahwa Pesan dakwah nahi mungkar dalam bentuk nasihat adalah dengan memberikan sebuah nasihat kepada orang yang melakukan perbuatan nahi mungkar. Allah pun menjelaskan perintah nasihat tersebut dalam Qs. An-Nahl ayat 125 yang memerintahkan manusia untuk menyeru dengan hikmah (alhikmah), pelajaran yang baik (mavidzah hasanah), dan membantah dengan cara yang baik (almujadalab).

Saling menasihati diantara sesama manusia merupakan suatu kewajiban. Jika seseorang melihat suatu perbuatan kemungkaran yang dilakukan orang lain, hendaknya orang tersebut menasihati orang yang berbuat kemungkaran. Akan tetapi, dalam memberikan suatu nasihat tidak anjurkan menggunakan kata-kata kasar atau kata-kata makian, sehingga membuat orang yang dinasihati merasa tidak terima atau tersinggung dan pesan yang disampaikan pun tidak akan sampai. Hendaknya, ketika akan memberi nasihat harus menggunakan bahasa yang baik lagi lembut, agar nasihat dapat masuk ke dalam hati dan diterima oleh orang yang dinasihati. Memberiksan nasihat merupakan salah satu cara seseorang dalam menuntun orang lain menuju kepada jalan yang baik (Suparta, 2015: 244).

Pesan dakwah nahi mungkar bentuk nasihat, dapat diartikan sebagai pesan dakwah yang memuat tentang ajaran-ajaran yang baik. Sebagaimana diterangkan dalam surat An-Nahl ayat 125. Dalam menyampaikan pesan dakwah dapat dilakukan dengan tiga cara atau metode yaitu dengan hikmah, pelajaran yang baik, dan berdebat dengan cara yang baik. Berdasarkan pada isi kandungan surat tersebut pesan dakwah nahi mungkar bentuk nasihat ini peneliti bagi menjadi tiga bagian yaitu nasihat berupa hikmah (petunjuk), nasihat berupa manidzah hasanah (peringatan), dan nasihat berupa mujadalah (teguran).

Pertama, pesan dakwah nahi mungkar bentuk nasihat berupa hikmah, dalam unggahan tersebut konten dakwah nahi mungkar bentuk nasihat berupa hikmah terdapat 13 pesan dakwah. Hikmah dapat didefinisikan sebagai perkataan yang tegas dan benar yang dapat membedakan antara yang hak dan yang bathil, dimana hikmah merupakan perpaduan antara pengetahuan, latihan, dan pengalaman (Said, 2015: 79). Dalam hal ini peneliti simpulkan bahwa pesan dakwah nahi mungkar bentuk nasihat berupa hikmah yaitu pesan dakwah yang berisi tentang pesan yang memiliki maksud yang jelas dan benar yang didasarkan pada ilmu dan pengalaman sehingga kebenarannya tidak dapat terbantahkan. Contoh temuan nasihat berupa hikmah pada unggahan akun instagram @indonesiatanpapacaran tersebut yaitu:

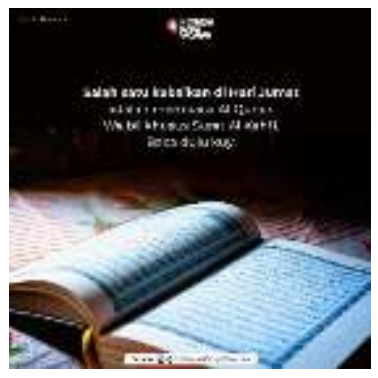




\section{Sumber: akun instagram@indonesiatanpapacaran \\ Gambar 4. Amalan Membaca Alquran}

Isi pesan pada gambar 4 memerintahkan tentang membaca surat Al-kahfi di hari Jumat. Alquran hendaknya dibaca setiap hari oleh setiap umat muslim, karena membacanya mendapat pahala juga memberikan banyak pelajaran dari setiap kisah-kisah yang telah Allah tuliskan dalam Alquran. Al-Kahfi merupakan surat ke-18 yang turun di Mekah, surat Al-Kahfi yang berarti para penghuni gua ini memiliki jumlah ayat sebanyak 110 ayat.

Membaca dan memahami isi kandungan Alquran merupakan dasar untuk dapat menjadikannya sebagai pedoman hidup. Tujuan dari pesan yang diunggah dalam akun instagram @Indonesiatanpapacaran tersebut menjadi bentuk ajakan kepada para pengikutnya agar senantiasa membaca dan mengamalkan ayat-ayat Alquran. Membaca Alquran sejatinya tidak hanya menunggu waktu luang, alangkah baiknya jika kita meluangkan waktu untuk bisa membacanya. Oleh karena itu, pesan dakwah dalam konten unggahan tersebut dimuat sebagai bentuk nasihat atau petunjuk kepada para pengguna media sosial agar kembali membaca kitab Alquran. Melakukan dakwah melalui media sosial menjadi sarana yang tepat pada saat ini. Teknologi informasi memberikan pengaruh yang cukup besar kepada masyarakat maupun individu (Sugiharti, 2014: 62).

Kedua, pesan dakwah nahi mungkar bentuk nasihat mavidzah basanah diartikan sebagai pesan nasihat berupa peringatan. Muidzah hasanah didefinisikan sebagai memberikan pelajaran yang baik. Kata al-mauidzah sendiri merupakan tindakan mengingatkan seseorang dengan baik dan lemah lembut sehingga orang diperingatkan hatinya menjadi lunak (Suparta, 2015: 243). Maka dari itu yang dimaksud dengan pesan dakwah nasihat berupa mauidzah hasanah dalam konten yang diunggah dalam media sosial yaitu pesan dakwah yang didalamnya terkandung peringatan bagi setiap orang yang mendengar atau membacanya.

Dalam unggahan tersebut pesan dakwah nahi mungkar benntuk nasihat berupa mavidzah hasanah terdapat sebanyak 20 pesan dakwah. Adapun contoh pesan dakwah nahi mungkar bentuk nasihat dalam konten unggahan akun instagram@indonesiatanpapacaran yaitu:

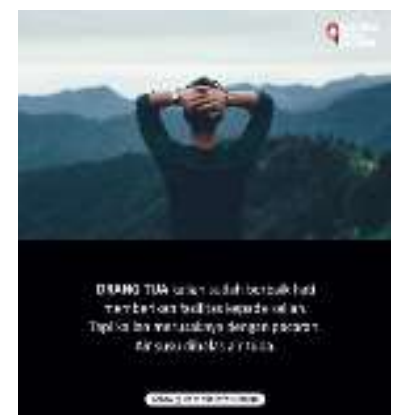

Sumber: Akun instagram@Indonesiatanpapacaran 
Gambar 5. Perintah berbakti kepada kedua orangtua

Isi pesan dakwah dalam unggahan pada gambar 5 mengingatkan kita tentang kasih sayang orangtua. Berbakti kepada kedua orangtua merupakan sebuah kewajiban yang harus dilakukan oleh anak. Salah satu cara agar dapat membahagiakannya yaitu dengan tidak membuatnya kecewa, yakni dengan cara menjauhi perbuatan-perbuatan yang dapat menjerumuskan kita pada kemaksiatan dan perzinahan.

Dewasa ini, media telah banyak mempengaruhi pergaulan dan sikap para generasi muda. Salah satu perilaku menyimpang yang banyak terjadi saat ini yaitu hilangnya rasa hormat terhadap orangtua. Banyak hal yang terkadang kita anggap biasa namun dapat membuat orangtua kita kecewa. Sebagaimana umat muslim ketahui bahwa berbakti kepada kedua orangtua hukumnya wajib dalam Islam. Perintah berbakti kepada kedua orangtua banyak disebutkan di dalam Alquran dan hadis. Apabila seorang anak tidak berbakti kepada kedua orangtuanya, maka baginyalah dosa yang amat besar. Untuk menyelamatkan pengaruh buruk dalam pergaulan para generasi muda saat ini, maka dibuatlah pesan dakwah dalam media sosial akun instagram@Indonesiatanpapacaran ini berupa peringatan sebagai cara untuk menangkal dampak buruk yang dipengaruhi oleh media. Media memiliki pengaruh yang cukup kuat dalam kehidupan manusia. Hal ini sejalan dengan fungsi media yaitu untuk mempengaruhi baik melalui gagasan maupun opini yang dibuatnya (Muhtadi, 2016: 21).

Ketiga, pesan dakwah nahi mungkar bentuk nasihat berupa mujadalah yaitu pesan nasihat yang berisi tentang nasihat yang disertai dengan argumen. Mujadalah termasuk ke dalam salah satu metode dakwah sebagaimana dijelaskan dalam surat An-Nahl ayat 125. Dakwah dengan melakukan perdebatan yakni dakwah yang disertai degan argumentasi yang kuat. Dengan bukti-bukti yang mampu mematahkan alasan atau dalil lawan yang menjadikannya tidak dapat bertahan (Said, 2015: 85). Dari penjelasan tersebut dapat peneliti simpulkan bahwa pesan dakwah nahi mungkar bentuk nasihat berupa mujadalah yaitu pesan dakwah yang mengandung argumentasi kuat sehingga isi pesan yang terkandung tidak dapat dibantah kebenarannya. Dalam unggahan tersebut pesan dakwah nahi mungkar bentuk nasihat berupa mujadalah terdapat sebanyak 9 pesan dakwah. Berikut merupakan temuan pada konten yang unggahan dalam akun instagram @Indonesiatanpapacaran yang termasuk pada nasihat berupa mujadalah.

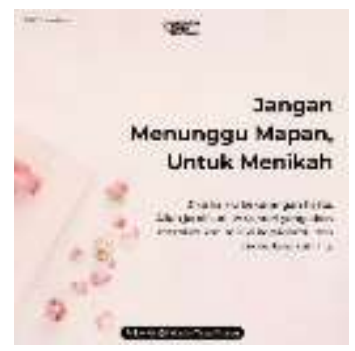

Sumber: akun instagram@Indonesiatanpapacaran

Gambar 6. Menikah tidak harus menunggu mapan 
Pada gambar 6 menerangkan bahwa menikah tidak ada kaitannya dengan kemapanan seseorang. Mapan atau tidaknya seseorang disebabkan karena kerja kerasnya yang dilakukannya baik itu sebelum atau sesudah menikah. Jika suatu kemapanan menjadi tolok ukur seseorang untuk menikah maka itu akan mempersulit seseorang untuk menikah. Materi merupakan salah satu aspek penting dalam kehidupan pernikahan. Namun, bukan berarti seseorang yang tidak mapan tidak dapat menikah. Selama dia sudah mampu secara mental maupun fisik untuk menikah, serta syarat rukun menikah terpenuhi maka pernikahan dapat dilaksanakan.

Fenomena ini membuat banyak generasi muda yang ingin segera menikah mengurungkan diri karena merasa belum mapan. Isi pesan pada konten unggahan media sosial instagram tersebut memuat tentang nasihat bahwa menikah tidak harus menunggu mapan. Maka dari itu pesan dalam unggahan akun @Indonesiatanpapacaran ini dimuat untuk membuat para pengikutnya atau generasi muda yang ingin menikah tidak terbebani karena masalah ketidakmapanan. Dalam suatu hadis dikatakan bahwa Allah akan menambahkan rezeki kepada seorang hamba yang ingin menikah karena ibadah. Karena dalam isi pesan pada konten tersebut memberikan argumentasi yang kuat bahwa Allah akan menambah rezeki seseorang ketika menikah, maka menikah menjadi bagian dari ibadah.

Dari penjelasan tersebut dapat dipahamibahwa pesan pada konten tersebut tidak lagi menjadi perdebatan, karena permasalahan rezeki merupakan kehendak Allah Swt. media sosial menjadi media penyebaran. Konten yang disebarkan dapat menjadi sarana untuk pembenaran suatu masalah atau sarana untuk menambah informasi sehingga para pengguna media sosial dapat menjadi paham (Nasrullah, 2016: 17).

\section{Pesan Dakwah Nahi Mungkar Bentuk Pencegahan}

Pencegahan merupakan suatu upaya yang dapat dilakukan agar sesuatu tidak terjadi. Dalam kamus besar bahasa Indonesia pencegahan adalah menahan agar sesuatu tidak terjadi (Dep.Diknas, 2008: 250). Pesan dakwah nahi mungkar bentuk pencegahan berarti suatu pesan yang dimaksudkan untuk mecegah suatu kemungkaran baik kemungkaran itu belum terjadi, sedang terjadi, maupun telah terjadi agar pelaku kemungkaran tersebut sadar dan tidak mengulanginya lagi. Memberikan pencegahan dengan perkataan-perkataan yang membuat orang tersebut takut untuk melakukan perbuatan nahi mungkar kembali dan kemudian menjauhinya (Ikhwani dan Iqbal, 2016: 56). Dalam hal ini peneliti menyamakan bentuk pencegahan tersebut dengan pengendalian sosial. Mengikuti kerangkan Syarbaini (2016: 138) terkait proses pengendalian sosial terbagi pada tiga sifat, untuk itu pesan dakwah nahi mungkar bentuk pencegahan ini, peneliti membaginya kepada tiga bentuk pencegahan, yaitu pencegahan bentuk preventif, pencegahan bentuk represif, dan pencegahan bentuk kuratif.

Pertama, preventif merupakan sifat pengendalian sosial yang dilakukan 
sebelum terjadi suatu pelanggaran. Sifat preventif ini bertumpu pada suatu proses pencegahan agar suatu pelanggaran tidak terjadi. Pesan dakwah nahi mungkar bentuk pencegahan preventif adalah suatu pesan dakwah yang dimaksudkan sebagai upaya untuk mencegah sejak awal agar kemungkaran tidak terjadi. Dalam unggahan tersebut pesan dakwah nahi mungkar bentuk pencegahan preventif sebanyak 22 pesan dakwah.

Berikut merupakan salah satu contoh pesan dakwah nahi mungkar bentuk pencegahan preventif yang terdapat dalam konten unggahan akun instagram (a) Indonesiatanpapacaran.

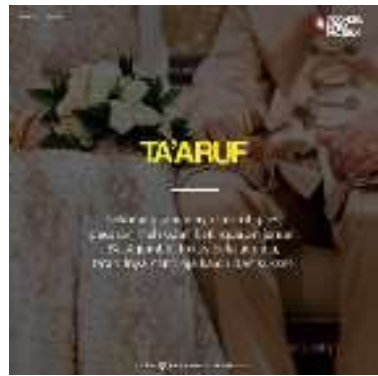

Sumber: akun instagram @Indonesiatanpapacaran

Gambar 7. Ta'aruf

Dalam gambar 7 menerangkan tentang salah satu bentuk pencegahan preventif dalam mencegah kemungkaran yaitu dengan ber-ta'aruf. Ta'aruf merupakan proses pengenalan diri antara satu sama lain dengan disertai suatu maksud atau tujuan tertentu yaitu untuk menyempurnakan ibadah. Tujuan dari ta'aruf sendiri yaitu agar saling mengenal satu sama lain baik secara fisik maupun non fisik sebelum menuju ke jenjang pernikahan.

Dikarenakan banyaknya remaja muslim yang kemudian dipengaruhi oleh media sosial untuk senantiasa berpacaran, maka dibuatlah alternatif yang berkaitan dengan pesan ta'aruf di dalam media sosial. Pesan pencegahan preventif tersebut ditujukan agar para pengguna mendapat pencerahan terkait dalam mengekspresikan perasaanya sebagaimana yang telah disyariatkan dalam ajaran Islam. Media sosial instagram inilah yang kemudian menjadi media yang efektif untuk mendakwahkan pesan ta'aruf pada generasi muda.

Generasi muda saat ini, ketika mereka ber-ta'aruf, mereka pasti mejalin hubungan pacaran. Untuk itu, pesan dalam akun instagram ini berupaya mendorong mereka untuk tidak berpacaran akan tetapi menjalani hubungan ta'aruf yang sesuai dengan syariat agama Islam. Sehingga pesan ta'aruf ini menjadi salah satu bentuk untuk mendidik generasi muda melalui media sosial. Sebagaimana salah satu fungsi media yaitu to educate atau memberikan pendidikan kepada masyarakat (Vera, 2016: 18).

Kedua, represif merupakan salah satu sifat pengendalian sosial yang dilakukan setelah seseorang melakukan suatu tindakan penyimpangan atau pelanggaran dengan menjelaskan dampak dari perbuatan yang dilakukan. Bentuk pencegahan represif ini bertujuan untuk menerangkan konsekuensi dari suatu 
perbuatan. Maka dari itu, pesan dakwah nahi mungkar bentuk pencegahan represif diartikan sebagai pesan dakwah yang dapat membuat orang yang melakukan perbuatan mungkar kembali seperti semula dengan cara menjelaskan akibat atau dampak yang ditimbulkan dari suatu perbuatan.

Dalam konten unggahan tersebut pesan dakwah pencegahan represif terdapat sebanyak 4 pesan dakwah. Berikut merupakan salah satu contoh pesan dakwah nahi mungkar yang terdapat dalam konten unggahan akun instagram @Indonesiatanpapacaran yang termasuk pada bentuk pencegahan represif.

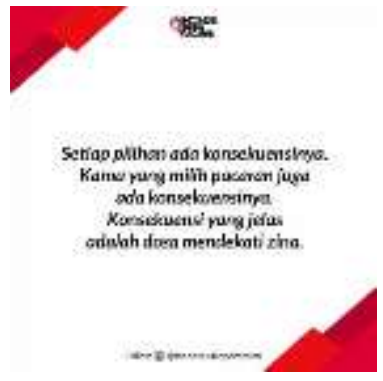

Sumber: Akun instagram @Indonesiatanpapacaran

Gambar 8. Konsekuensi berzina

Dalam gambar 8 isi pesan tersebut menjelaskan suatu konsekuensi yang diterima oleh seseorang yang melakukan perbuatan nahi mungkar. Pada pesan tersebut diterangkan bahwa konsekuensi dari melakukan hubungan berpacaran adalah dosa. Dosa merupakan perbuatan yang melangggar hukum yang telah ditetapkan oleh agama. Menjalin hubungan pacaran termasuk ke dalam dosa karena melakukan tindakan yang tidak dihalalkan.

Sebagaimana diketahui bahwa jika seseorang melakukan suatu perbuatan yang mungkar maka konsekuensi dari perbuatan tersebut adalah dosa. Isi pesan dakwah dalam konten unggahan tersebut dibuat sebagai bentuk pencegahan represif dengan memberitahu suatu konsekuensi dari suatu perbuatan, dengan tujuan agar orang yang melakukannya tidak kembali mengulanginya. Hal ini sejalan dengan fungsi dari media itu sendiri sebagai media pengawasan. Media sebagai pengawasan peringatan yaitu dengan menginformasikan tentang suatu akibat dari suatu perbuatan (Vera, 2016: 22).

Ketiga, kuratif merupakan bentuk pengendalian sosial yang dilakukan setelah terjadinya suatu tindakan penyimpangan melalui tindakan penyadaran. Bentuk pencegahan kuratif ini bertujuan untuk memulihkan para pelaku pemyimpangan agar tidak mengulangi tindakan yang menyimpang. Sedangkan pesan dakwah nahi mungkar dalam bentuk pencegahan kuratif ini berarti pesan dakwah yang di dalamya terkandung pesan penyadaran atau pemulihan kepada orang yang melakukan perbuatan mungkar agar mau memperbaiki kehidupannya dengan cara bertaubat.

Dalam unggahan tersebut didapat sebanyak 6 pesan dakwah yang termasuk pada pesan dakwah nahi mungkar bentuk pencegahan kuratif. Berikut merupakan 
salah satu temuan dalam konten yang diunggah pada akun instagram @Indonesiatanpapacran yang termasuk pada bentuk pencegahan kuratif.

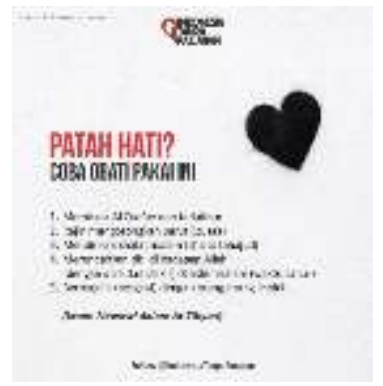

Sumber: Akun instagram @indonesiatanpapacaran

Gambar 9. Patah hati

Isi pesan dakwah yang terdapat pada gambar 9 menerangkan tentang akibat yang akan didapatkan oleh seseorang yang menjalin hubungan pacaran yiatu patah hati. Patah hati merupakan suatu keadaan dimana seseorang merasa tidak ingin melakukan aktivitas apapun dan bahkan dapat menyebabkan seseorang depresi karena suatu alasan.

Tidak sedikit dari mereka yang ketika putus mereka akan merasakan patah hati. Maka dari itu pesan dakwah dalam unggahan akun instagram tersebut memberikan pencegahan bersifat kuratif agar para pelaku pacaran ketika mereka merasakan patah hati untuk tidak mengulangi perbuatannya kembali. Cara yang efektif untuk menyembuhkan penyakit hati yaitu dengan banyak mendekatkan diri dengan Allah Swt.

Pesan dakwah dalam konten unggahan tersebut dilakukan sebagai bentuk pencegahan kuratif agar pelaku kemungkaran mendapat efek jera dari perbuatan yang telah dilakukannya tersebut. Media sosial dalam konteks ini berfungsi sebagai pengawasan isntrumental dimana dalam penyampaian informasinya memiliki kegunaan atau dapat membantu dalam kehidupannya (Vera, 2016: 22).

\section{PENUTUP}

Setelah melakukan analisis isi terhadap pesan dakwah nahi mungkar pada konten gambar atau caption serta video yang diunggah dalam akun instagram @)Indonesiatanpapacaran pada bulan Februari 2019, didapat sebanyak 134 gambar atau caption dan 28 video mengandung pesan dakwah nahi mungkar.

Pesan dakwah nahi mungkar bentuk penjelasan dalam akun instagram @indonesiatanpapacaran terdapat sebanyak 50 pesan dakwah berupa gambar dan 11 pesan dakwah video, dari jumlah tersebut bentuk penjelasan dibagi pada tiga kategori yaitu aspek akidah, aspek syariah, dan aspek akhlak. Pesan dakwah nahi mungkar bentuk penjelasan pada aspek akidah berkaitan dengan iman kepada Allah, iman kepada kitab, dan iman kepada Qada dan Qadar. Pesan dakwah nahi mungkar bentuk penjelasan pada aspek syariah yaitu berkaitan dengan anjuran beribadah dan menjaga diri. Anjuran beribadah dalam konten tersebut yaitu 
anjuran berdakwah, bekerja, dan berdoa. Sedangkan konten yang membahas anjuran menjaga diri seperti berpuasa sebagai bentuk melawan hawa nafsu. Sedangkan pesan dakwah nahi mungkar bentuk penjelasan pada aspek akhlak berkiatan dengan akhlak terpuji dan akhlak tercela. Akhlak terpuji yang ditemukan dalam konten pada instagram tersebut membahas tentang hijrah, sedangkan akhlak tercela membahas terkait perbuatan zina.

Pesan dakwah nahi mungkar bentuk nasihat pada konten akun instagram @Indonesiatanpapacaran terdapat sebanyak 35 pesan dakwah berupa gambar dan 7 pesan dakwah video. Pesan dakwah nahi mungkar bentuk nasihat terbagi pada tiga kategori, yaitu pesan nasihat berupa hikmah, pesan nasihat berupa mavidzah basanah, dan pesan nasihat berupa mujadalah. Nasihat berupa hikmah yaitu berkaitan dengan pesan Istiqomah, Membaca surat Al-Kahfi di hari Jumat, dan hidayah. Nasihat berupa mauidzah hasanah berkaitan dengan pesan berbakti kepada orang tua, memanfaatkan waktu, dan memperbaiki diri. Sedangkan nasihat berupa mujadalah dalam konten unggahan tersebut berkaitan dengan pesan hukum berzina, Istidraj, dan rezeki.

Pesan dakwah nahi mungkar bentuk pencegahan pada konten yang diunggah pada akun instagram @Indonesiatanpapacaran terdapat sebagai 25 pesan dakwah visual dan 7 pesan dakwah video. pesan dakwah nahi mungkar bentuk pencegahan terbagi atas tiga kategori diantaranya bentuk pencegahan preventif, bentuk pencegahan represif, dan bentuk pencegahan kuratif. Adapun pesan dakwah bentuk preventif yang ditemukan pada konten instagram tersebut berkaitan dengan pesan Beramal, Ta'aruf, dan perintah taat kepada Allah. Pesan dakwah bentuk pencegahan represif di dalam konten unggahan tersebut berikatan tentang pesan patah hati, dan dosa pacaran. Sedangkan bentuk pecegahan kuratif, pesan dakwah yang ditemukan pada konten instagram tersebut membahas tentang pesan berhijrah setelah melakukan dosa, dan putus meneyelamatkan diri dari perzinahan

Berdasarkan hasil penelitian analisis isi pesan dalam konten unggahan akun instagram@Indonesiatanpapacaran, pesan dakwah tersebut banyak membahas tentang dakwah nahi mungkar khususnya tentang larangan berpacaran dalam Islam. Hal ini selaras dengan visi dari gerakan Indonesia Tanpa Pacaran yang ingin berjuang menghapus pacaran dari Indonesia.

Adapun saran kepada peneliti selanjutnya yang akan menjadikan media sosial sebagai objek penelitian diharapkan dapat lebih mengkaji lebih dalam mengenai dakwah di media sosial dari aspek lainnya seperti menggunakan pendekatan semiotika, pendekatan analisis wacana, dan metode-metode lainnya.

\section{DAFTAR PUSTAKA}

Abidin, Z. (2017). Kontekstualisasi Hijrah Sebagai Titik Tolak Pembaharuan Pendidikan. Subuf. 29(1), 50-65.

Aziz, M. A. (2009). Ilmu Dakwah. Jakarta: Kencana Prenada Media Grup 
Departemen Pendidikan Nasional. (2008). Kamus Besar Bahasa Indonesia Edisi Keempat Pusat Bahasa. Jakarta: PT Gramedia Pustaka Utama

Enterprise, J. (2012). Instagram untuk Fotografi Digital dan Bisnis Kreatif. Jakarta: Kompas Gramedia

Hartono, T. A. (2018). 130 Juta Orang Indonesia Tercatat Aktif Aktif di Medsos. Diakses tanggal 19 Februari 2019. https://inet.detik.com/cyberlife/d3912429/130-juta-orang-indonesia-tercatat-aktif-di-medsos

Herman. (2017). Strategi Komunikasi Pengelolaan Zakat, Infak, dan Sedekah (ZIS) Melalui Media Sosial. Communicatus: Jurnal Ilmu Komunikasi. 1 (2), 171 190.

Ikhwani, dan Iqbal, M. (2016). Nahi Munkar dalam Perspektif Islam. Lentera.16 (19) 51-58.

Ismail, I. (2011). Filsafat Dakwah Rekayasa Membangun Agama dan Peradaban. Jakarta: Kencana Prenadamedia Group

Kamaluddin. (2016). Pesan Dakwah. FITRAH: Jurnal Kajian Ilmu-ilmu Keislaman. 2 (2), 37-58.

Khalika, N. N. (2018). Cara Indonesia Tanpa Pacaran Mengikat Ratusan Ribu Pengikut. Diakses pada tanggal 18 Juli 2019. https://tirto.id/cara-indonesia-tanpapacaran-memikat-ratusan-ribu-pengikut-cLgQ

Kusnawan, A. (2016). Tehnik Menulis Dakwah. Bandung: Simbiosa Rekatama Media

M Pakhri, A. (2017). Penggunaan Fitur Vidgram sebagai Tren media Dakwah (Studi Deskriptif Kualitatif Pada Akun @Yuvid.tv di Instagram). Skripsi. Ilmu Komunikasi. UIN Alauddin Makassar

Metropolis. (2017). Angka Nikah Muda Masib Tinggi 90 Persen Hamil Duluan. Diakses 21 Maret 2019. https://pontianakpost.co.id/angka-nikah-mudamasih-tinggi-90-persen-hamil-duluan

Muhaemin, E. (2017). Dakwah Digital Akademisi Dakwah. Ilmu Dakwah: Academic Journal for Homiletic Studies. 11 (2), 341-356.

Muhtadi, A. S. (2012). Komunikasi Dakwah : Teori, Pendekatan, dan Aplikasi. Bandung : PT. Remaja Rosdakarya

Musthofa, (2016). Prinsip Dakwah Via Media Sosial. APLIKASLA. 6. (1), 51-55.

Nasrulloh, R. (2015). Media Sosial perspektif komunikasi, Budaya, dan Sosioteknologi. Bandung : Simbiosa Rekatam Media

Said, N. M. (2015). Metode Dakwah (Studi Alquran Surah An-Nahl Ayat 125). Jurnal Dakwah Tabligh.16(1), 78-89

Soliha, S. F. (2015). Tingkat ketergantungan pengguna media sosial dan kecemasan sosial. Jurnal Interaksi. 4 (1), 1-10

Sugiharti, R. (2014). Perkembangan Masyarakat Informasi dan Teori Sosial Kontemporer. Jakarta: Kencana Prenada Media Grup

Sukayat, T. (2009). Quantum Dakwah. Jakarta: Rineka Cipta

Suparta, M., dan Hefni, H. (2015). Metode Dakwah. Jakarta: Prenadamedia Group

Tohari, L. A., Fatoni, U., \& Muhlis, A. (2019). Strategi Dakwah Santri Dalam Menghadapi Berita Hoax di Media Sosial. Tabligh: Jurnal Komunikasi dan Penyiaran 
A. Muharam, S. Sumijaty, \& U. Fatoni

Islam, 5(2), 148-167

Vera, N. (2016). Komunikasi Massa. Bogor: Ghalia Indonesia

Yanti, R. (2009). Analisis Isi Pesan Dakwah dalam Sinopsis Film Mengaku Rasul. Skripsi. KPI. UIN Syarif Hidayatullah Jakarta 